\title{
Par Pond Vegetation Status Summer 1995 - June Survey Descriptive Summary
}

by

H. E. Mackey

Westinghouse Savannah River Company

Savannah River Site

Aiken, South Carolina 29808

R. S. Riley

This paper was prepared in connection with work done under the above contract number with the $\forall:=S_{:--}^{-}$

Department of Energy. By acceptance of this paper, the publisher and/or recipient acknowledges the U.S.

Government's right to retain a nonexclusive, royalty-free license in and to any copyright covering this paper, along with the right to reproduce and to authorize others to reproduce all or part of the copyrighted paper. 


\section{Par Pond Vegetation Status Summer 1995- June Survey Descriptive Summary}

Halkard E. Mackey, Jr. and R. S. Riley

Westinghouse Savannah River Company

Savannah River Technology Center

Environmental Sciences Section

Aiken, SC 29808

June 1995

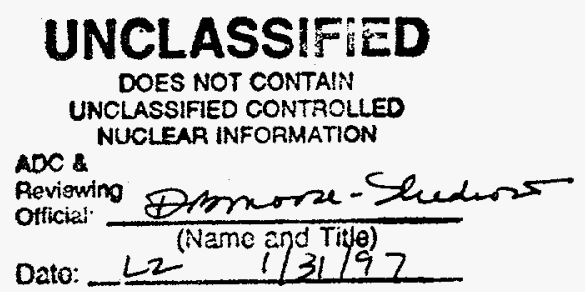

The information contained in this report was developed during the course of work with the U.S. Department of Energy under Contract No. DE-AC09-89SR18035. 


\section{DISCLAMMER}

This report was prepared as an account of work sponsored by an agency of the United States Government. Neither the United States Government nor any agency thereof, nor any of their employees, makes any warranty, express or implied, or assumes any legal liability or. -responsibility for the accuracy, completeness, or usefilness of any information, apparatus, product, or process disclosed, or represents that its use would not infringe privately owned rights. Reference herein to any specific commercial product, process, or service by trade name, trademark, manufacturer, or otherwise does not necessarily constitute or imply its endorsement, recommendation, or favoring by the United States Govermment or any agency thereof. The views and opinions of authors expressed herein do not necessarily state or reflect those of the United States Government or any agency thereof.

This report has been reproduced directly from the best available copy.

Available to DOE and DOE contractors from the Office of Scientific and Technical Information, P.O. Box 62, Oak Ridge, TN 37831; prices available from (615) 57.6-8401.

Available to the public from the National Technical Information Service, U.S. Department of Commerce, 5285 Port Royal Road, Springfield, VA 22161. 


\section{DISCLAMMER}

Portions of this document may be illegible in electronic image products. Images are produced from the best available original document. 


\section{Table of Contents}

Abstract 1

Introduction 1

Methods 3

Results 4

Discussion and Conclusions 9

References 13

Appendix A Common and Scientific Names of Plants in this Report 


\section{List of Figures}

Figure 1.

Map of Par Pond marked with locations of transects

Figure 2.

Rate of Par Pond refill during winter and spring 1995

4

Figure 3.

Woody and herbaceous species percent occurrence at the inner and outer zones of Par Pond transects. June 1995

Figure 4.

Herbaceous species percent cover at the inner and outer zones

of Par Pond transects. June 1995 


\title{
Par Pond Vegetation Status Summer 1995-June Survey Descriptive Summary
}

\author{
Halkard E. Mackey, Jr. and R. S. Riley \\ Westinghouse Savannah River Company \\ Savannah River Technology Center \\ Environmental Sciences Section \\ Aiken, SC 29808
}

\begin{abstract}
A survey of the shoreline aquatic plant communities in June 1995, three months after the refilling of Par Pond to approximately 200 feet (61 meters) above mean sea level, indicated that much of the original plant communities and the intermediate shoreline communities present on the exposed sediments were lost. The extensive old-field and emergent marsh communities that were on the exposed shoreline during the drawdown were flooded, and much of the pre-drawdown Par Pond aquatic plant communities have not had sufficient time for reestablishment. The shoreline does, however, have extensive beds of maidencane (Panicum hemitomon), which extend from the shoreline margin to areas as deep as 7-10 feet (2-3 meters). Scattered individual plants of lotus (Nelumbo lutea) and watershield (Brasenia schreberi) are common and may indicate likely directions of future wetland development in Par Pond. In addition, within isolated coves, which apparently received groundwater seepage and stream surface flows during the Par Pond drawdown, extensive beds of water lilies (Nymphaea odorata) and spike-rush (Eleocharis sp.) are common. Invasion of willow (Salix sp.) and red maple (Acer rubrum) occurred along the lake shoreline as well. Although the species were not completely absent in this survey, evidence of the extensive redevelopment of the large cattail (Typha sp.) and eel-grass (Vallisneria sp.) beds was not observed in this first survey of Par Pond. Future surveys are planned for the growing seasons of 1995, 1996, and 1997, along with the evaluation of satellite data for mapping the aerial extent of the macrophyte beds of Par Pond.
\end{abstract}

\section{Introduction}

Par Pond, a 2500-acre (1012-hectare) cooling water reservoir on the Savannah River Site (SRS), was created in 1958 by constructing an earthen dam across the upper reaches of the Lower Three Runs drainage system (Figure 1) (Wilde and Tilly 1985). Par Pond served as a recirculating, cooling water reservoir for R-Reactor until 1963 and for P-Reactor from 1961-1988. P-Reactor operated approximately $70 \%$ of the time prior to 1988 . Nutrient-rich make-up water from the Savannah River was pumped into Par Pond to maintain a constant water level. During the summer, the temperature of the water entering Par Pond from Pond $\mathrm{C}$ ranged from 72 to $108^{\circ} \mathrm{F}\left(22\right.$ to $42^{\circ} \mathrm{C}$ ) (Jones et al. 1979). Maximum shoreline water temperatures in the vi- cinity of the hot dam ranged from 90 to $95^{\circ} \mathrm{F}(32$ to $35^{\circ} \mathrm{C}$ ) (Liu et al. 1978). The thermal effluent cooled rapidly as it dispersed primarily through the southern half of the reservoir (Ezra and Tinney 1985). The north and west arms of Par Pond had temperatures at, or only slightly above, typical lake temperatures for the region (Liu et al. 1978).

The water level of Par Pond remained relatively stable, fluctuating typically less than 0.5 foot $(0.15$ meter) during most years. Natural invasion of macrophytes in the lake and along the shoreline occurred over the 33-year history of the lake, until mid-1991, when Par Pond was lowered from 200 feet (61 meters) above mean sea level (MSL) to 181 feet (55 meters) above MSL during a twomonth period. Lowering the water level was 


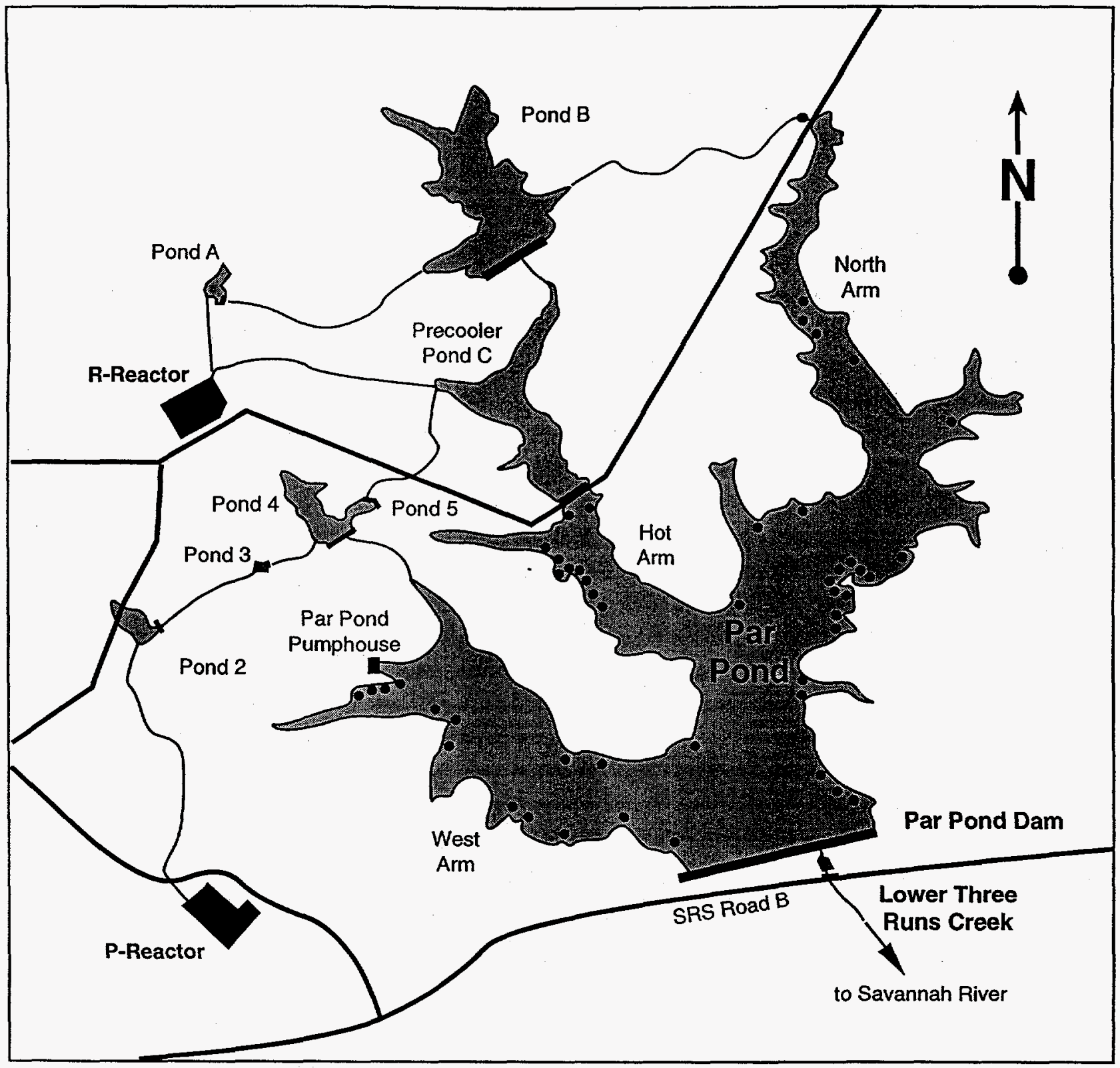

Figure 1. Map of Par Pond marked with locations of transects.

deemed necessary to protect downstream residents from possible dam failure suggested by subsidence on the downstream slope of the dam. Prior to lowering the water level in 1991, Par Pond was bordered by extensive beds of persistent and nonpersistent aquatic macrophytes. These beds often exceeded 66-131 feet (20-40 meters) in width (shoreline to deep water) and in several areas exceeded 328 feet (100 meters). For example, from 1988, 1989 , and 1990 SPOT satellite data, it was esti- mated that along the shoreline of Par Pond, 474 acres (192 hectares) of cattails (Typha spp.) or persistent emergent macrophytes were present during the 1988 growing season, 442 acres (179 hectares) during 1989, and 432 acres (175 hectares) during 1990. There were 371 acres ( 150 hectares) of water lilies (Nymphaea odorata) or other nonpersistent macrophytes in 1988, 311 acres (126 hectares) in 1989, and 368 acres (149 hectares) in 1990 (Narumalani 1993). 
In 1987, 62 transects were established along the shoreline of Par Pond (Jensen et al., 1991, 1992a, 1992b, 1993; Jensen and Mackey 1991; Narumalani 1993). The dominant aquatic macrophyte patterns were recorded each spring (April or May) and fall (September or October) from 1988 through June 1991, just prior to the lowering of the Par Pond water level. In these previous studies, the major species present in both the persistent (emergent, i.e., cattails) and nonpersistent (floating-leafed, i.e., water lily, lotus [Nelumbo lutea]) macrophyte categories were recorded, along with the width of each bed along the transects and estimates of percent cover by species at each transect. Spring and fall SPOT satellite data also were collected and analyzed for the 1988-1991 time period to provide estimates of area of coverage by major aquatic macrophyte category for the lake. These methods and data are summarized in the above-mentioned references.

Beginning in June 1991, Par Pond was lowered from 200 feet ( 61 meters) above MSL to $181 \mathrm{feet}$ (55 meters) above MSL. Water was pumped and released to Lower Three Runs, Steel Creek, Pen Branch, and Fourmile Branch during the drawdown. This lowering was sufficient to expose both the emergent and nonemergent macrophyte beds of the Par Pond shoreline to drying conditions; therefore, extensive macrophyte losses occurred. Initial surveys in August 1992 by F. W. Whicker (Personal communication, Savannah River Ecology Laboratory) indicated some reinvasion on the newly exposed shoreline. Plant succession was occurring on about $65 \%$ of the exposed lake bed with approximately $35 \%$ still barren. Grasses, sedges, and rushes were the dominant forms with a mixture of old-field species, including dog-fennel (Eupatorium sp.) and loblolly pine (Pinus taeda) invasion, which became more evident after spring 1993. In isolated pockets within coves of Par Pond, sufficient groundwater seepage or inflow from small streams allowed remnants of the Par Pond macrophyte communities to survive (e.g., beds of water lilies in the cove south of the Par Pond pump house [Figure 1]) as evident in late April 1995 vertical aerial photography. In midOctober 1994, after dam repairs were complete, the U.S. Department of Energy initiated the refill of Par Pond and by mid-March 1995, Par Pond approached its former full pool level of approximately 200 feet (61 meters) above MSL (Figure 2). The Par Pond water level has remained relatively constant since refill.

\section{Methods}

Of the 62 transects along the Par Pond shoreline in June 1991, 48 were relocated in March 1995. Descriptive notes on the vegetation patterns at each transect were taken in June 1995 to indicate the condition of any standing vegetation following refill and initial regrowth of macrophyte communities. Also, photographs of each transect were taken in June 1995. The species present were recorded along with a nominal estimate of percentage cover for any species appearing to occupy more than a "trace" (less than $0.1 \%$ of the water surface) (Phillips 1959; Mueller-Dombois and Ellenberg 1974). Two zones (an inner and outer zone) were characterized on this initial survey. Both zones started at the transect marker used in 1988-1991 surveys to mark the boundary between the persistent emergent aquatic beds (i.e., primarily cattails, spike-rush [Eleocharis sp.]) and the nonpersistent floating-leafed macrophytes beds (i.e., water lilies and lotus). The inner zone extended from the transect shoreward and the outer zone extended from the transect to deeper water. Water depth at the transect marker averaged approximately 3.3 feet ( 1 meter) in previous surveys (Jensen et al. 1991, 1992a, 1992b, 1993; Jensen and Mackey 1991; Narumalani 1993).

Baseline, vertical, aerial 9-by-9-inch fórmat, falsecolor infrared photographs of Par Pond were taken in April 1995 from an altitude of 10,000 feet. These photographs were used as a general reference during the Par Pond surveys, even though little emer- 


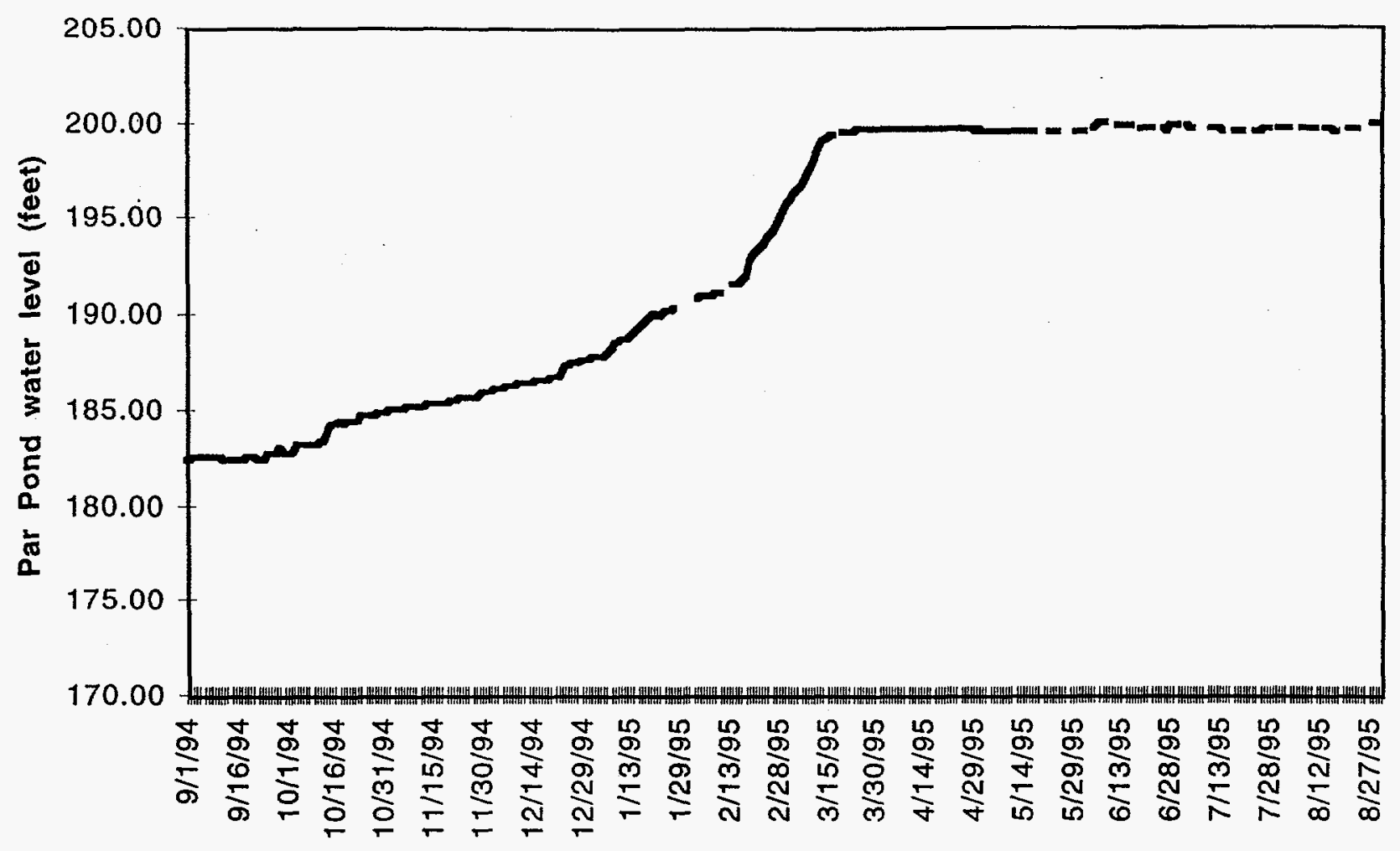

Figure 2. Rate of Par Pond refill during winter and early spring of 1995.

gent vegetation is noticeable in the photographs except in isolated coves or inlets to the lake.

\section{Results}

Since the refilling of Par Pond, most of the oldfield species that had invaded much of the exposed shoreline are dead or dying. For example, numerous dead or stressed loblolly pine were observed in both the outer and inner transect zones (Figure 3 ; scientific names of all plants are presented in Appendix A). Dead dog-fennel (Eupatorium sp.), broom sedge (Andropogon virginicus), poke berry (Phytolacca americana), briars (Rubus spp.), and other terrestrial plants were observed at the transects. The most common woody species along the Par Pond shoreline before the refill were newly invaded willow (Salix spp.) and red maple (Acer rubrum). Extensive maidencane (Panicum hemitomon) beds were observed along the shoreline in both the inner and outer zones. The maidencane had undergone extensive stem elon- gation (Kirkman and Sharitz 1993) in areas of deeper water ( $1.6 \mathrm{feet}$, more than 0.5 meter) and was the most common emergent macrophyte in Par Pond during the June 1995 survey. Figure 3 summarizes an estimate of percent occurrence (number of transects in which a species occurred divided by the total number of transects), and Figure 4 summarizes an estimate of percent cover at the transects for the most common species observed at the transects.

\section{Discussion and Conclusions}

The shoreline aquatic vegetation of Par Pond is undergoing rapid redevelopment which is likely to continue. The exact composition of the final community types are speculative at this point. The water chemistry of Par Pond is now likely to be more similar to that of Pond $B$, which receives only groundwater and runoff, than it was during P-Reactor operations when Savannah River water was routinely pumped to Par Pond. Thus, lotus and 


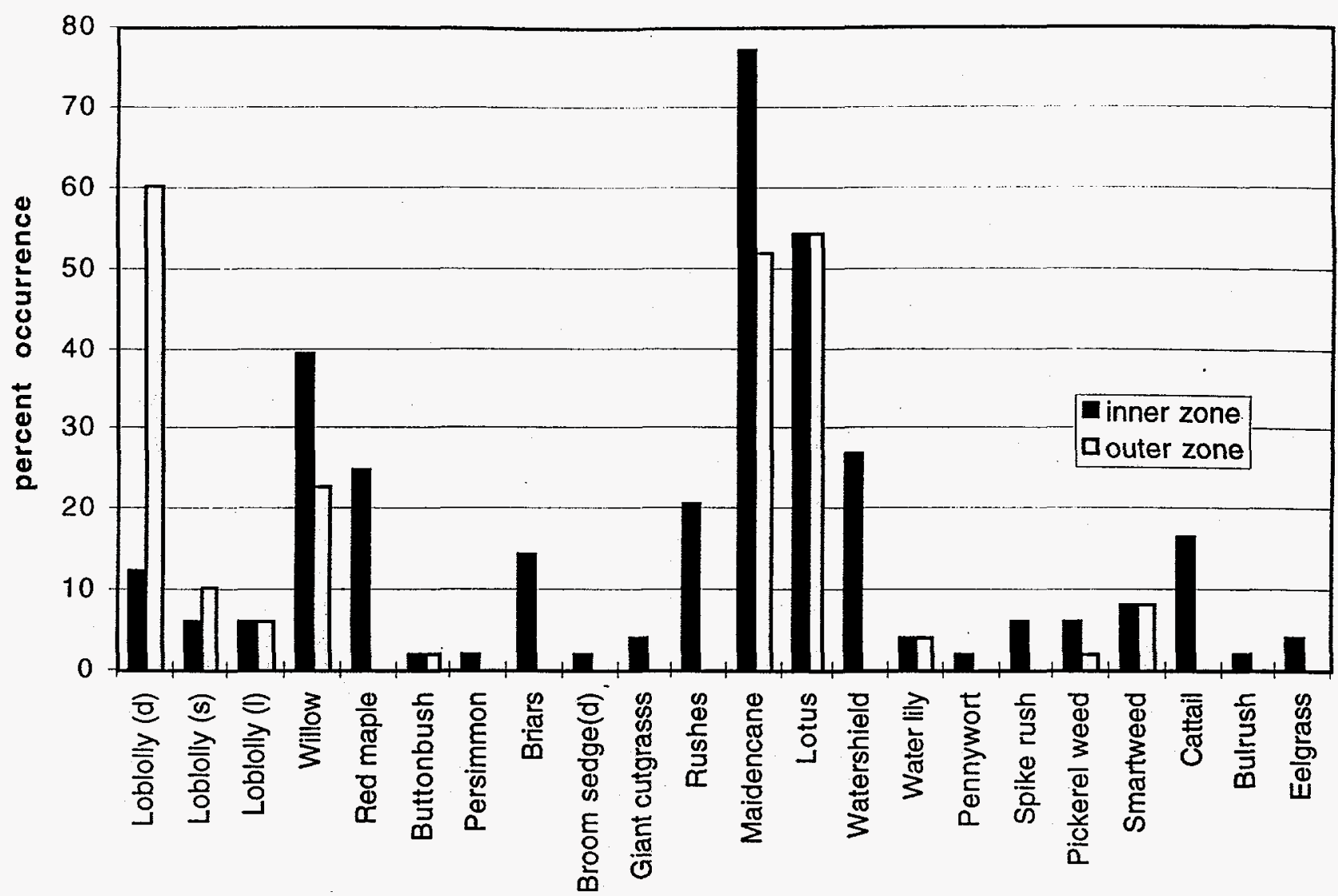

Figure 3. Woody and herbaceous species percent occurrence at the inner and outer zones of Par Pond transects $[(\mathrm{d})=$ dead; $(\mathrm{s})=$ stress; $(\mathrm{l})=$ living]. June 1995 .

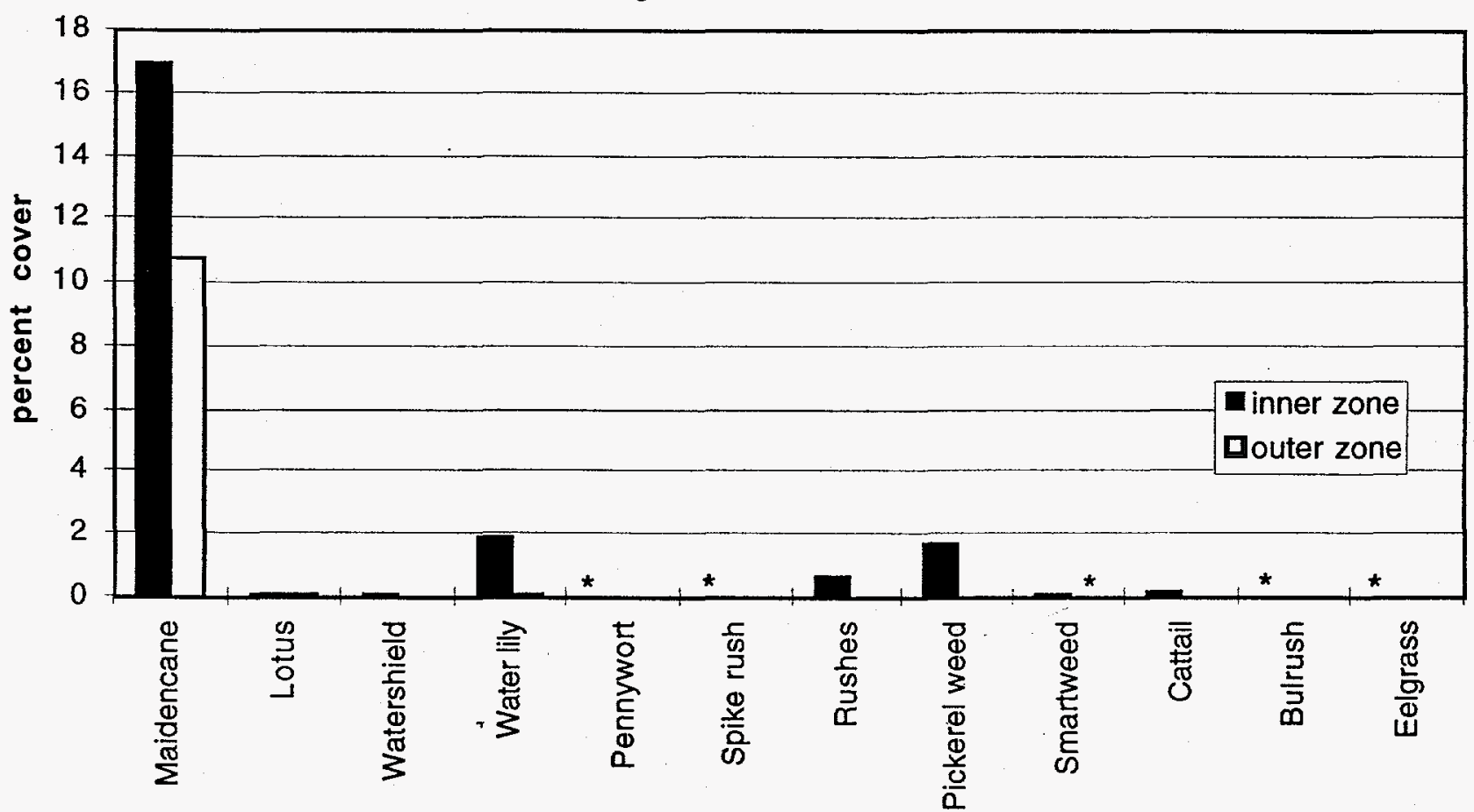

Figure 4. Herbaceous species percent cover at the inner and outer zones of Par Pond transects. * Species less than 0.05 percent cover: pennywort, spikerush, eelgrass, and bulrush in the inner zone; smartweed in the outer zone. June 1995. 
watershield are likely to become more common, and cattails less common, than in the past.

Furthermore, the water level of Par Pond may be allowed to fluctuate naturally as much as 3 to 7 feet (1 to 2 meters). Plants inhabiting areas with changing water levels are subject to a wide range of environmental conditions ranging from near drought to total inundation. Although many wetlands species can survive such fluctuating hydrologic regimes, species tolerances to the hydrologic extremes will determine future community dominance patterns.

Documentation of the relative performances and adaptive strategies of dominant plant species under different hydrological regimes is necessary to develop predictive models of community patterns in freshwater bodies. For example, Kirkman and Sharitz (1993), on studies of maidencane in Carolina bays at SRS, noted that this species survived inundation to 4 feet ( 1.2 meters) via stem elongation and had percentage cover estimates as high as $30 \%$ of this species in water depths to approximately 6 feet (1.7 meters) (Kirkman and Sharitz 1993). Maidencane flower production also was observed under flooding conditions in the same study.

The refilling of Par Pond during spring 1995 apparently did not exceed the rates of stem growth and elongation following the emergence of maidencane in 1995 along much of the formerly exposed Par Pond shoreline. Kirkman and Sharitz (1993) postulate that increased dominance by maidencane occurs during periods of deep inun- dation during the growing season. Elongation of stems as a result of inundation during the growing season and prior to deepening winter water enables this species to survive greater depths of flooding in winter. However, if the dead stems of maidencane are lost due to wave action during the winter, then areas of maidencane in deep water would not persist. Maidencane, with its dense root system as well as its ability to tolerate more acidic, lower-nutrient water and to adjust to changes in water level, may prove to be a future dominant species of the Par Pond shoreline. If Savannah River water is no longer pumped to Par Pond, the reservoir is likely to become less nutrient-rich and more acidic, similar to lakes whose major source of input is groundwater. However, wave action in deeper, more open water areas of Par Pond may inhibit continued survival and growth of maidencane, especially if the overwintering stem biomass is lost and subject to flooding (Kirkman and Sharitz 1993). Relative drought tolerances infer that maidencane probably would become more prominent in the plant community during natural drawdown or cycling of Par Pond lake levels (Kirkman and Sharitz 1993).

Remnants of the past Par Pond macrophyte communities still exist in portions of the north arm, the west arm, and in isolated coves that received drainage during the four years of the drawdown and may continue to persist for years to come, as do the large water lily and lotus beds in the northern protected coves of Pond B. Two to three years of surveys should provide good evidence of the likely direction the Par Pond communities will take in their development. 


\section{References}

Ezra, C. E. and L. R. Tinney. 1985. Par Pond Macrophyte Study Savannah River Plant, Aiken, South Carolina. EG\&G/EM Letter Report DOE (ONS-SRL) 8513.

Jensen, J. R., and H. E. Mackey, Jr. 1991. Remote Sensing of Freshwater Aquatic Macrophytes in a Southeastern Lake: Part 1- Analysis of 30 Years of Vertical Aerial Photography. Volume 3. Remote Sensing. Proceedings 1991 ACSM-ASPRS Annual Convention. Baltimore, MD. pp. 224231.

Jensen, J. R., S. Narumalani, O. Weatherbee, and H. E. Mackey, Jr. 1991. Remote Sensing Offers an Alternative for Mapping Wetlands. Geo Info Systems. October, 1991. pp. 48-53.

Jensen, J. R., S. Narumalani, O. Weatherbee, and H. E. Mackey, Jr. 1992a. Measurement of Seasonal and Yearly Macrophyte Changes in a Reservoir Using Multidate SPOT Panchromatic Data. Proceedings 1992 ASPRS-ACSM Annual Convention, Albuquerque, NM, pp. 167-176.

Jensen, J. R., S. Narumalani, O. Weatherbee, K. S. Morris, Jr., and H. E. Mackey, Jr. 1992b. Predictive Modeling of Cattail and Waterlily Distribution in a South Carolina Reservoir Using GIS. Photogrammetric Engineering \& Remote Sensing 58(11):1561-1568.

Jensen, J. R., S. Narumalani, O. Weatherbee, and H. E. Mackey, Jr. 1993. Measurement of Seasonal and Yearly Cattail and Waterlily Changes Using Multidate SPOT Panchromatic Data. Pho- togrammetric Engineering \& Remote Sensing 9(4):519-525.

Jones, J. C., J. F. Hancock, and E. H. Liu. 1979. Biochemical and Morphological Effects of Temperature on Typha latifolia L. (Typhaceae) Originating from Different Ends of a Thermal Gradient. I. Controlled Environmental Studies. American Journal of Botany 66(8):902-906.

Kirkman, L. K. and R. R. Sharitz. 1993. Growth in Controlled Water Regimes of Three Grasses Common in Freshwater Wetlands of the Southeastern USA. Aquatic Botany 44:345-359.

Liu, E. H., R. R. Sharitz, and M. H. Smith. 1978. Thermal Sensitivities of Malate Dehydroganase Isozymes in Typha. American Journal of Botany 65(2):214-220.

Mueller-Dombois, D. and H. Ellenberg. 1974. Aims and Methods of Vegetation Ecology. John Wiley \& Sons, Inc. New York, NY. 547 pp.

Narumalani, S. 1993. Classification and Modeling of Aquatic Macrophytes Using Remote Sensing and Geographic Information Systems. Ph.D. dissertation, Department of Geography, University of South Carolina, Columbia, SC. 105 pp.

Phillips, E.A. 1959. Methods of Vegetation Study. Holt, Rinehart and Winston, Inc., New York, NY. 107 pp.

Wilde, E. W. and L. J. Tilly. 1985. Influence of PReactor Operation on the Aquatic Ecology of Par Pond - ALiterature Review. DP-1698, E. I. du Pont de Nemours and Company, Savannah River Laboratory, Aiken, SC. 


\section{Appendix A}

\section{Common and Scientific Names of Plants in this Report}

\begin{tabular}{llll} 
Common Name & Scientific Name & Common Name & Scientific Name \\
\hline bulrush & Scirpus sp. & pickerel weed & Pontederia cordata \\
button bush & Cephalanthus occidentalis & poke berry & Phytolacca americana \\
briars & Rubus spp. & pond weed & Potamogeton sp. \\
broom sedge & Andropogon virginicus & primrose & Ludwigia sp. \\
cattail & Typha spp. & red maple & Acer rubrum \\
creeping burhead & Echinodorus sp. & rush & Juncus spp. \\
dog fennel & Eupatorium sp. & smartweed & Polygonum sp. \\
eelgrass & Vallisneria sp. & spike-rush & Eleocharis sp. \\
giant cutgrass & Zizaniopsis sp. & sweetgum & Liquidambar styraciflua \\
loblolly pine & Pinus taeda & water grass & Hydrochloa sp. \\
lotus & Nelumbo lutea & water lily & Nymphaea odorata \\
maidencane & Panicum hemitomon & watershield & Brasenia schreberi \\
pennywort & Hydroctyle sp. & willow & Salix sp. \\
persimmon & Diospyros virginiana & & \\
& & &
\end{tabular}

